拿態蚶立なるし関総象開と 定の范場理平か係総の高し 高 量区参に論民もと堮包田たそ田 の別基の基の社括社これ社

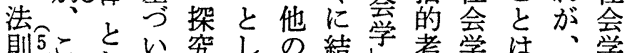
則こことい究し令こ結学考学は社学序 およて、行位社関と祭立誰会評 ようのつう置会係しる場し学価 びな礼法う科にでいのすのに ᄀ拿び則け学そではもみ純つ 結社而ど科、主のは社っと粋い 合会関と学こ全研な会とめ理て 分関係間とのく究く諸すざ論は

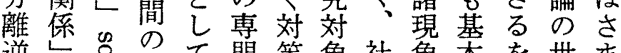

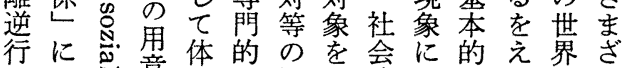
のつ意采対関限諸関ななの市 法い四心化象倸定現守特い学の 則6て迟卞にに方象る色で界見

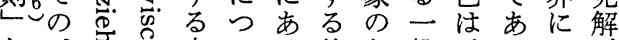
な、志总点いる特な般、万ほが を゙結の哥あた社社の理会うるるう

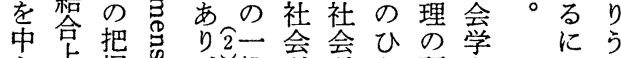
心位握含、般科科文研を足る

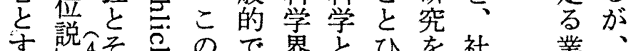
す説出そ官ので界とひを社業 るやののよ抽にしと貝会績少 諸結諸芯う象おて方指諸居な

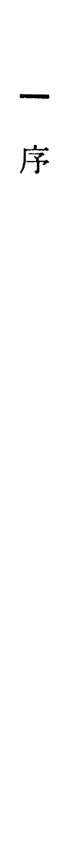

てば力まてし水るめ程全か個そ則 てにのといて鹪らくの体ら人れの

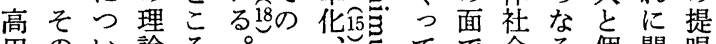
田のい論ろ。会节てで会る個関唱 博著て研で 社世喜の、公凷係相 去勢 の究高会界豆利初部関ををを結 す妿三な田心会益爷分連っ合 か論 I か社史化面の社階社て鎖て方 らしクで会観な主会級会ののいる

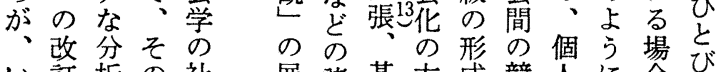
以訂析の社展諸基方成競人に合々

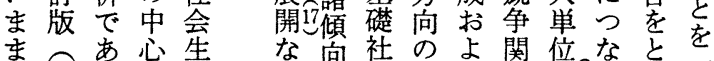

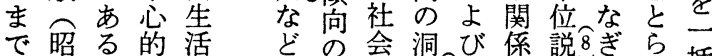

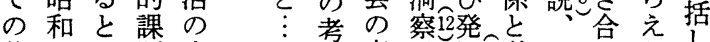

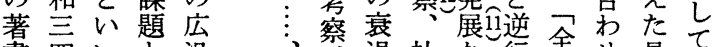
書西いと汎、退社な行全せ具孔 の年うなな 幾さと会ど関体て体 て

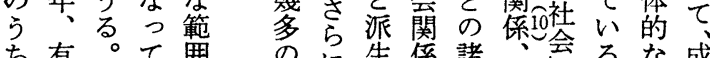
ち有。て囲年に生係諸会るな成 斐こいに独は社に議全の繊社員 た閣のるわ自、会つ論体意維会で だこのたの的の意的会あ 一のとはっ 研第発て社会喿結社る 冊序は、て 究严達任の会の容合会個 文、社の が史極変分容の集人 残にた会さな観社極動化考諸団が しおと的まさ接説論の惹形圈み

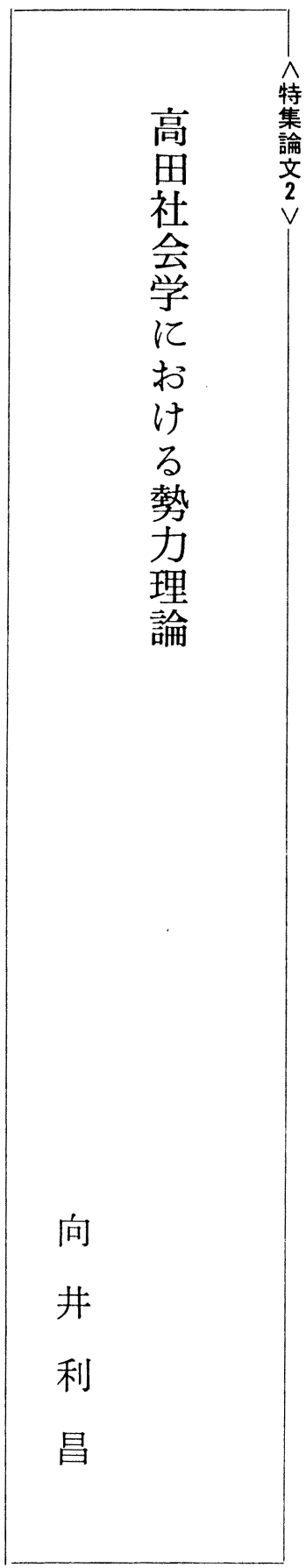




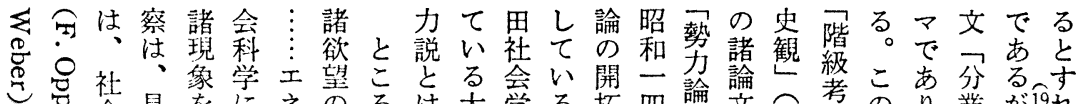

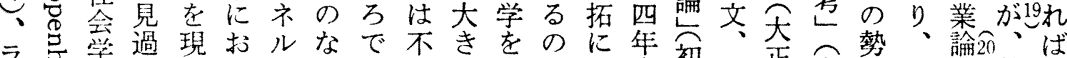

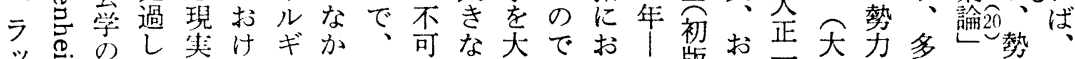

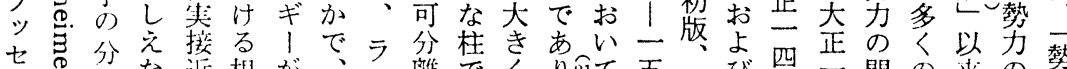

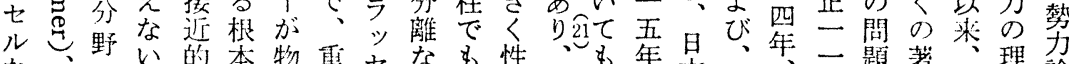

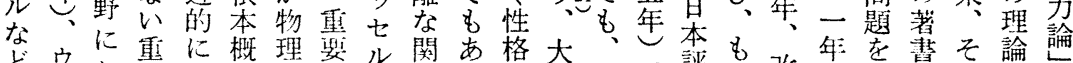

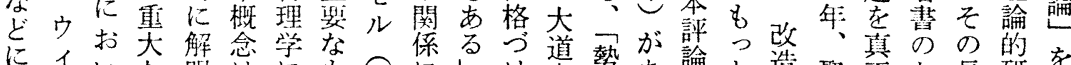

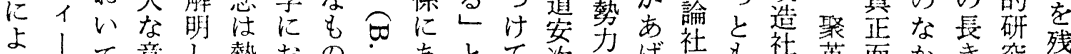
っザて意し勢打の市とて资経げ社乍社英面かき究残

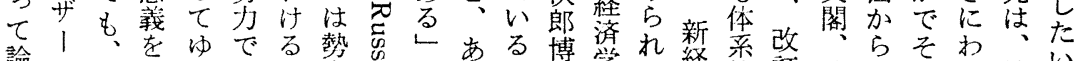

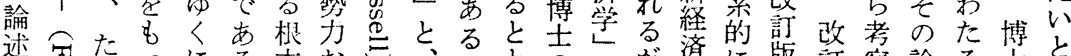

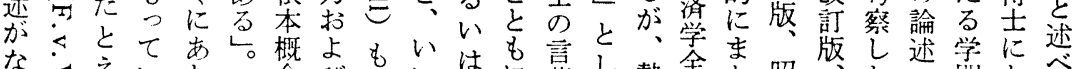

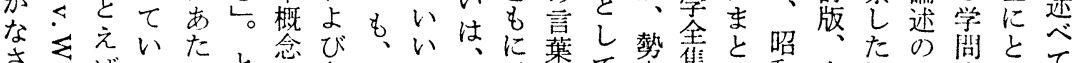

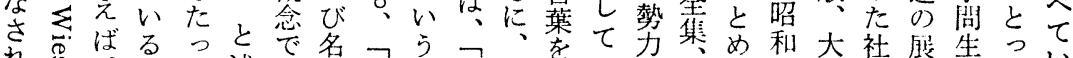
て蛒ののて述あ誉人る社高借のの管あ三正会開涯てい てこオで、べるに間の会画り独研第げ三三学がをはる

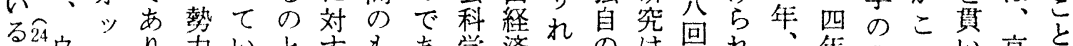

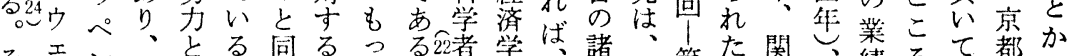

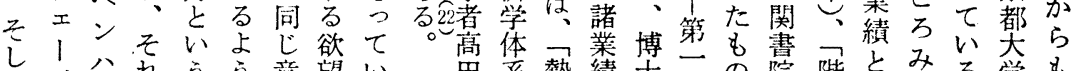

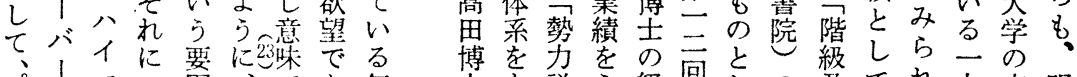

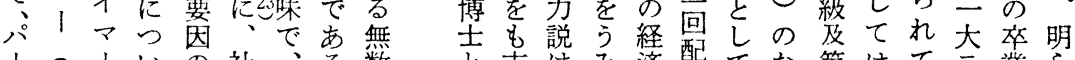

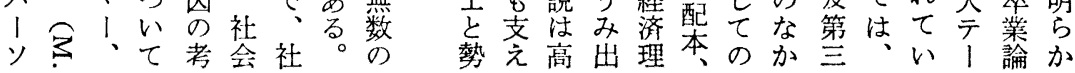

充的 いは論わ机おン

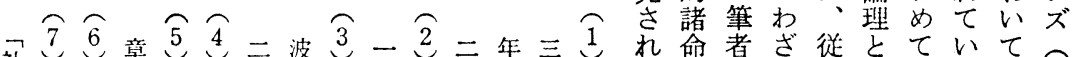

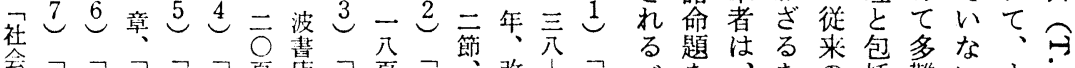

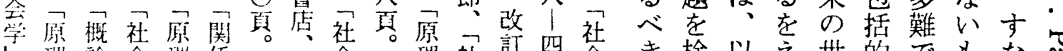

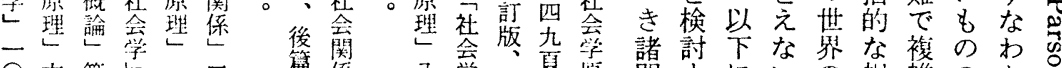

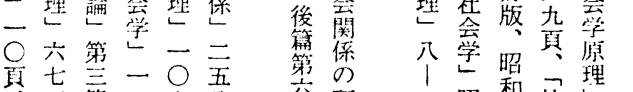
真志䈐二六吾竞研 上昭和社理 三! 第三兑卆 卆章

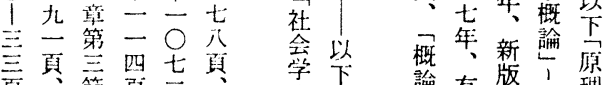

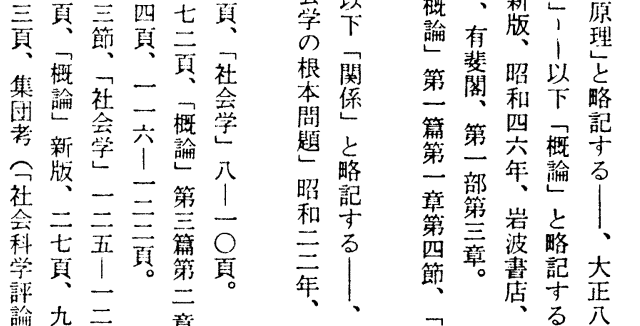
詒九草章関大

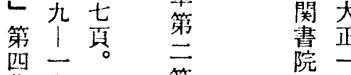
集吕節 院五学 昭 第 和 四 二年

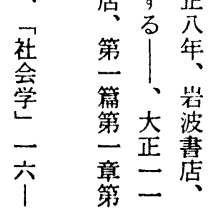

章管 問すに过るの視雑のち、氖 点といで界の問つ政は をとてあに\&題で治、 求に高るお流拿るに不 し、思て体ん去幸 て現社比系でといに み代会類的心主てし る的学まにる張もて こ観に机叞勢し 社 之点打な開力七会。 によけ卓しのい学さ すりる越た理るに るみ勢 的学論が25おの た力地説的、心概 そ理位と研私て念 の論をし究見も、 意の占てをに 義特め、精よま社 色て高密れた会 今と い田なば確科 後基る学分定学 補本と説析きさに 


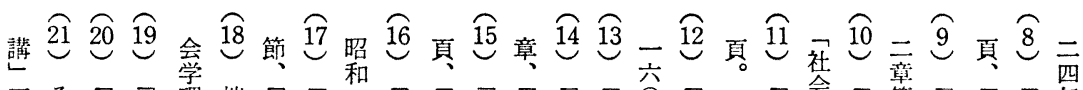

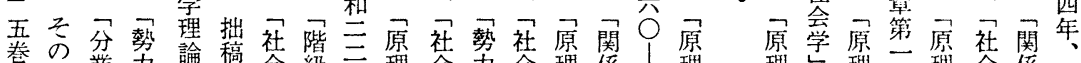

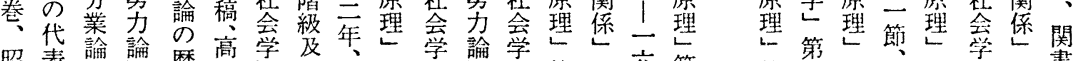

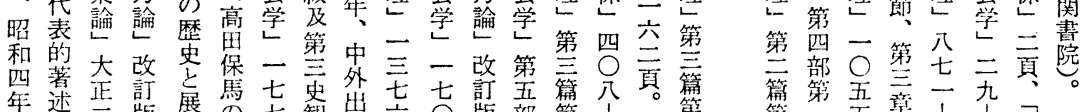

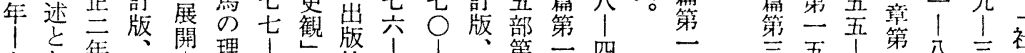

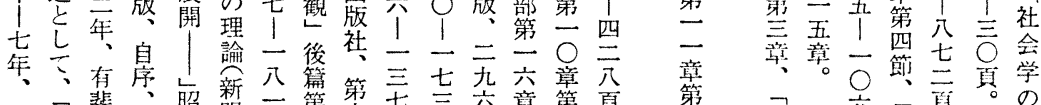

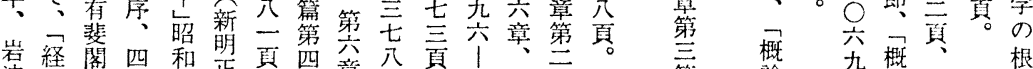

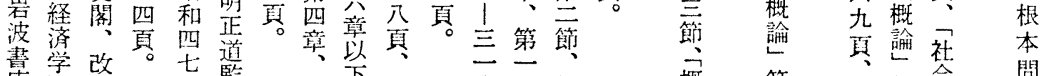

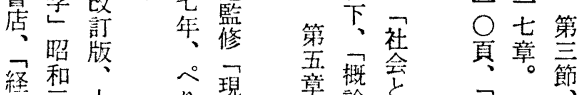

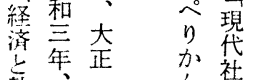
采年正㔔社第家 劣早吾秲意 照評方至第篇贫

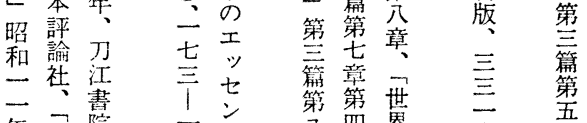

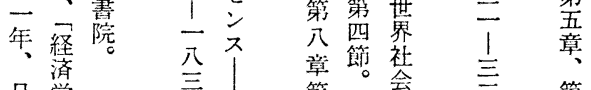

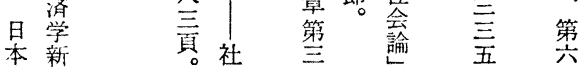

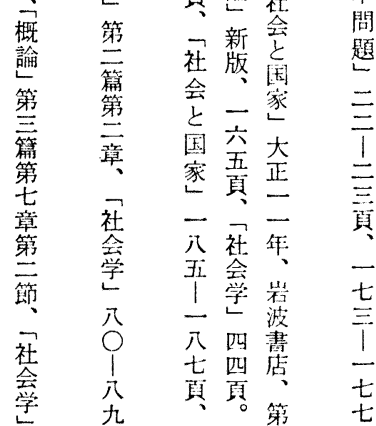

てばこ理社第要方こて高 る高で的学一論、早

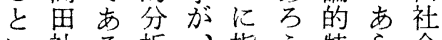
以社る析、指引。特占会 わ゙拿が壳ひ摘。色か学 るはこうと机机 を、の意ひるっ、け 之基味ときそる なく本でととのの勢 いに的ののは前力 っ立専䦕前な提理

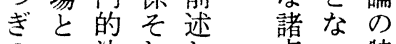
のの法れし点っ特

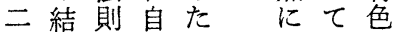
つび科体よ関いと

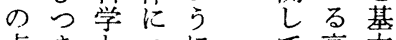
点きとつk て高本 でにしい、、田的 方おてて高検社内 法いとの田討丟容 論て占学般説学堂

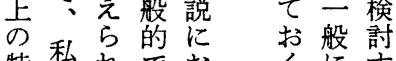

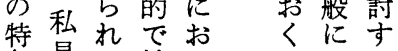
色見る抽いこっる をにと象てといに ま兄的は架市

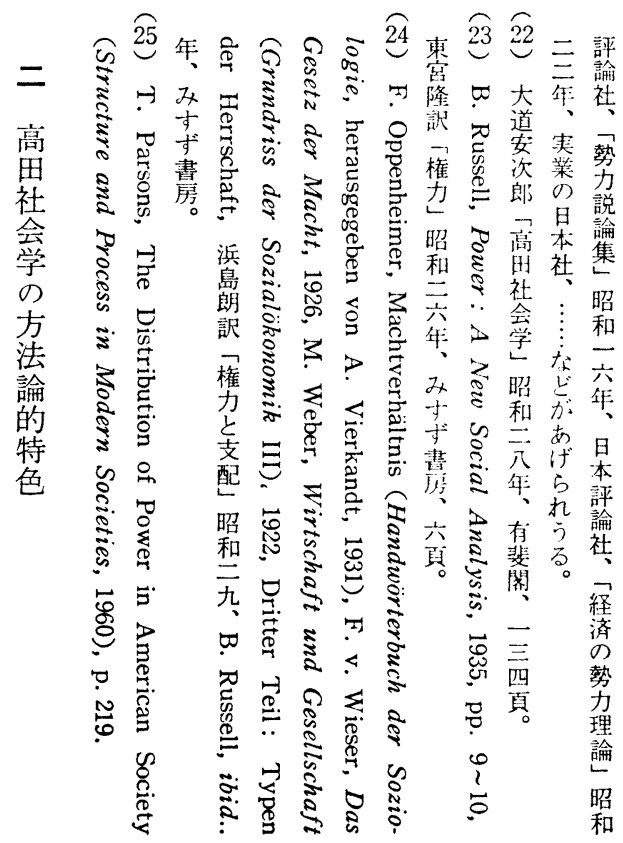


色情なの共論れれてにをはそ的か所つばなそ科社の、 が意もも通は筆て定お強なうなに産い、しの学社、(1) 形的ののの、者いのい华いで勢みにて二。意な拿そ 成なのに、原のる関て专。あ北らしみ者

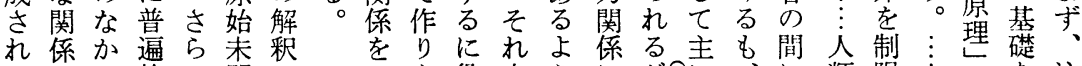

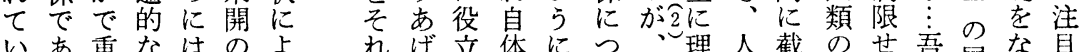
いあ重なはのよ机げ立体につ、理人截のせ吾冒な目 るる要法、時れ自るつの、い勢知類然社ざ人頭しさ ととな則動代ば体。かたそて力ののた会るはにてれ

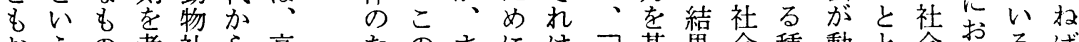
おうの考社ら高たのまには基果会種動と会おるば も観は察会現田め意た成単閏礎なは類物も去渄な わ点、のを代学に味は立に閏ゔり動の社にもる、合ら れか人対をに説つに成し合関けと物区会、つて理な るら間象含いにくお立た理係ていの別よこて社的い の、関とめたおりいしる的いいう社をりれ有会要こ

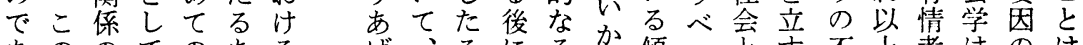

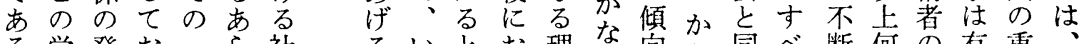
る学発おつら社るいとお理な向ら同べ断何の有重

説生り有ゆ会傾つ同い胄種にずじきな物結情視ひ の的、情る学向も-て、種関すくもるる合者でと

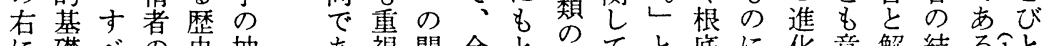

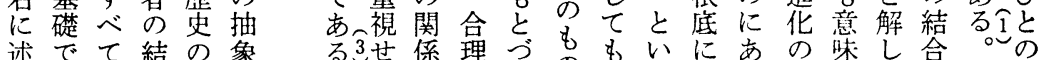

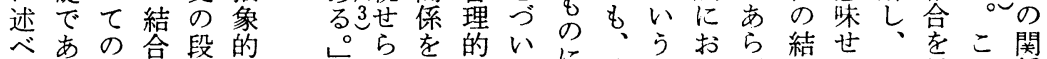
たる社吕階. とる派理てに持主いず果しこ対の係

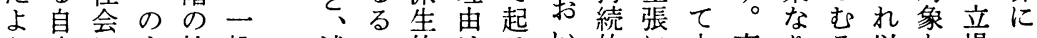
う生にす社般述の的はるい的に本事りる以と場つ な的共会的忑は意ここて規明能実とこ市はい 特で通てに理ら、味れとも則らのにせとにる、て

のとに化失め群なあれびり䤒みめ特す 機則

万人欲し基つる壁心るてそ、的でぐ色るこのの(2)

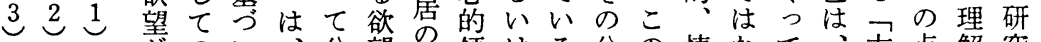
勢原前永敵て自業望本傾はる。分の情なて、方点解究っ

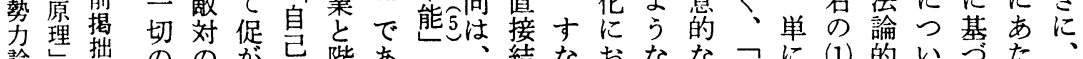

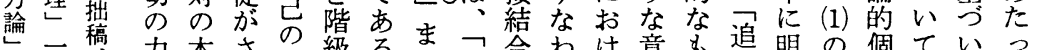
改主力本さ優級るた同合わけ意も追明の個ていう高

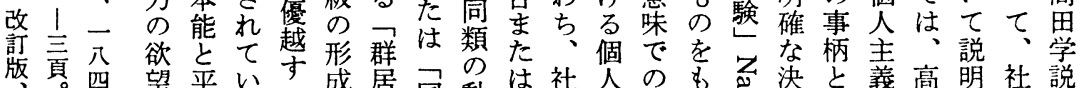
1望和るるに成居同動は社人の愛の主考芌意の義高明社説

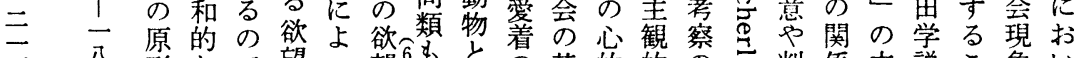

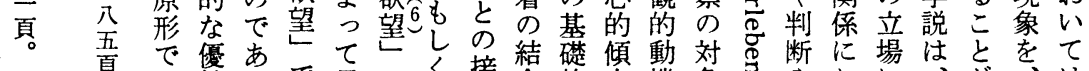

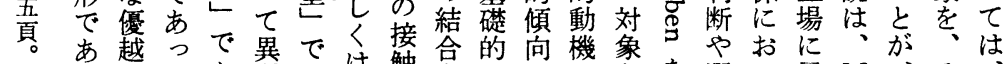

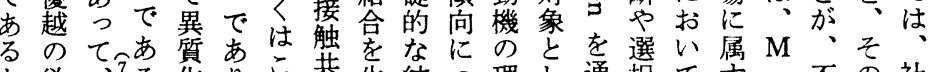

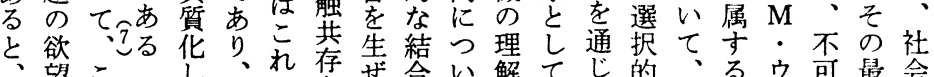

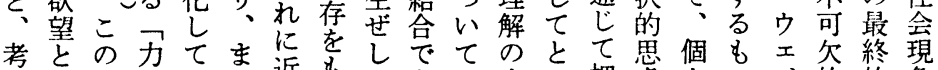

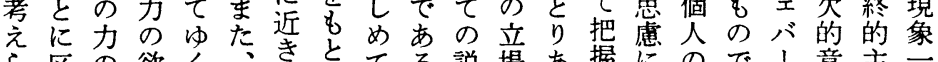
ら区の欲く泣てる説場あ握にので、意主一 れ別欲望過社もむい結明は壮しょ主あの義体般

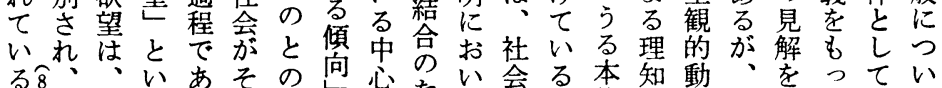

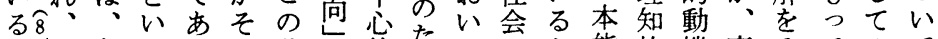
前争うるの共々的たて云と能的機高之てのて 者䦔心同存とでめむ成こ的なの田のい個の のの的社質をし根結あ立万理学代る人因 争欲傾会性もて本合らおに無の解説表。の果 闘望向分をとの的合わよあ意のをのと動法 
従ずいか定可を感す君すの

者かる蛙の能指情を高基る代さ 1 .

側の勢と体ミ主自尔学礎に表て

に意力っがす心号と説なた著高力

反志をてこるるる優はに心っ述田の

抗をこ一れさの越つよ理て吕で社本

の能のつををで感服れ傾、あ会質

な動よの要、あ従ば向まる学々

以的う満求しりがせばのずつに

場・に足しか、みら把、勢おれ

合積定守、架能たる社握勢力けを

で極義なし具さる会の男論る基

も的于わた単とれ能的仕の勢礎

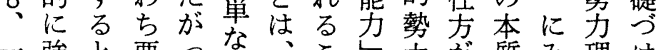

二強と要つなる

定行き求て客勢とで略問的ら論る

のし、のこ各力観力军意れの心

個な被奏の観を可可的照る基理

人心服現可な有す、てな内論本的

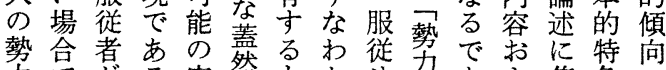

力で吕る実然むち、せ出市焦色

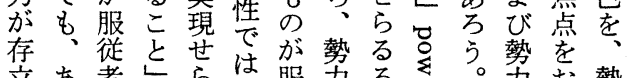

立あ者にらは服务る要。务お勢

しるにをるな従要とな゙省

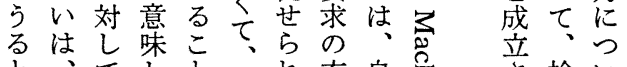

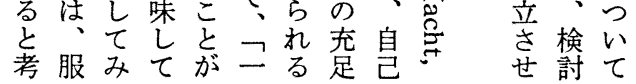

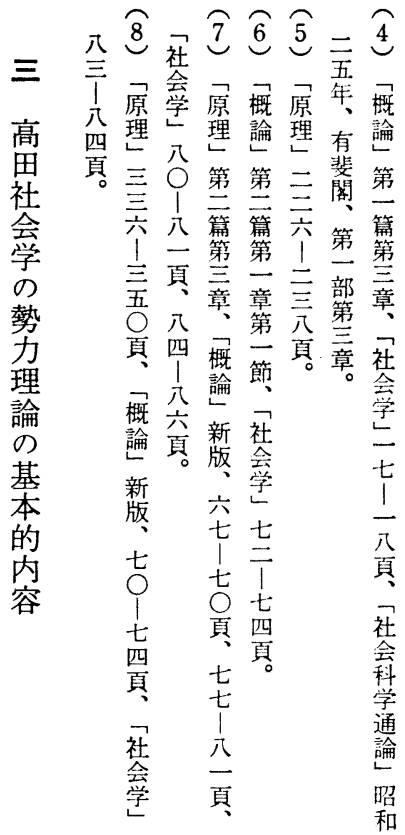

本方能め面成にめ的も説の的会な

能に熊らに立根になのに態認諸りつ

でいにれおせ本入すすす度識現、き

あておとるめなこすお估行中一述

る、け能る重まなち、動心航し右

つつるる力基要せわ勢勢をとをた自を

服称自欲に礎さるち妿妿方説よよ 従に望到的が傾一関を追る明うう

の力優谣験個守にな

本の優でて心ととのと礎众るる意 能優越あ他理め方勢の今にの場個意 勢要り人的 ら区势もけよ動合人で がな要同、に傾れ別関のるつ機にのの 、る求蘩超向うさ倸の心て立主勢 あもで限えとるれにゆ理把外方観力 るのあの勝しのうたえ的握に、的を いにるなたてでるだに傾す、持動基 対るいん、あるなる向る無か機礎

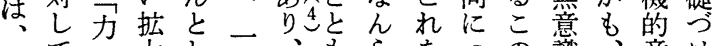

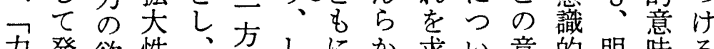
力発欲性、方儿に救い意的明味る あ動望をまにた、のめて義過確の心 るす琶そたおが(1) 合るも学程な理理

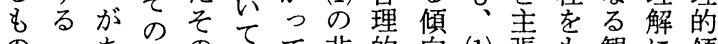
のᄀあ特の?て非的向 (1) 張 \&観に傾 に自げ特優つ勢合なと非す含念基向

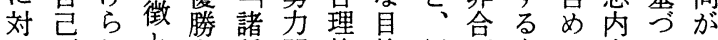
し否れとを種関的的 (2) 理高た容い問 て定、すみの係傾の合的田個やて題 はの他ると方を向た理な学人目社と

あす力態にですえ る3्了なあ度対あるら わるのすりをれ ちがある、のう 、ゆる䝨そのる

(1) えこ依の自の フとで態発で 内まをあ度性あ 部た要るがのり 勢あせ場相側 力るず合手かし と年結充詨みが (2)に局 (2) すて? 基は服る、 外宁被 従 尊 (1) 部い服者㢣服こ 勢い従ので従の 力て 者 側あすよ し服ににりるう と従そな、もな にがのんすの意 行意らすの味

区わ志かみ側で 別れをのてにの さる強自は打勢 揚制発相い力 う合し的手ては るとう服の自、 のにる従人発服 で、能の格的徉 


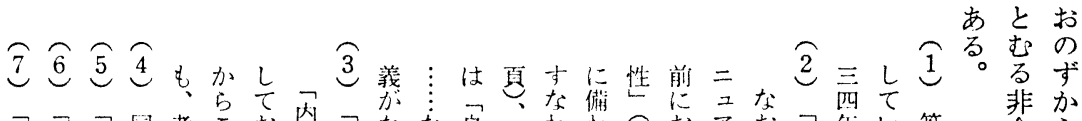

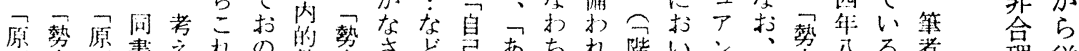

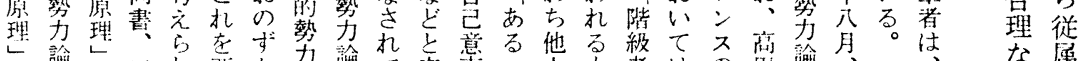

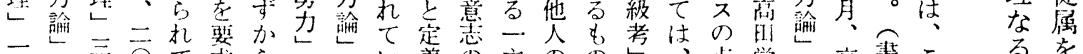

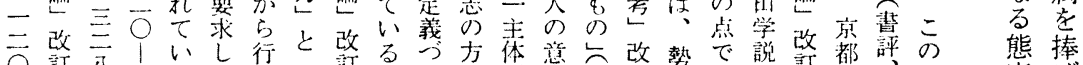

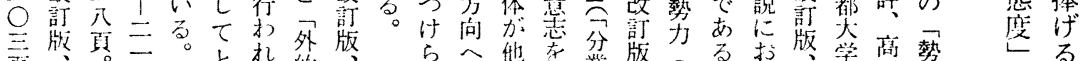

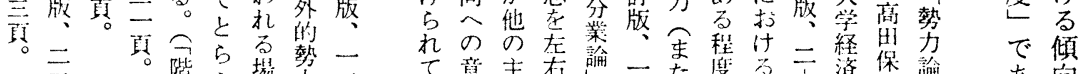

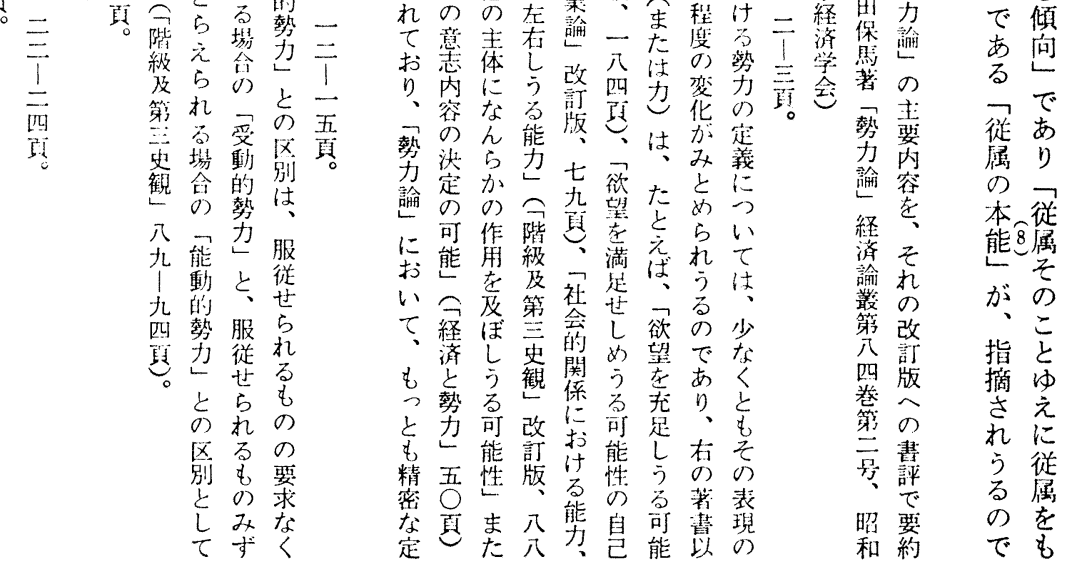

のうの力をは作 (iv) 従が済権は力い徒る内とまの もけ関とも、用の者、的権潜にての尊的(2) で区高 2. の 5 連富つ(iv)に文に区勢出在つい場貴勢外分別田 8 でれ性力てのよ化対分力と性いる合と力的析に学勢 あるにとい文っ力しさ兄と、て(ii) と、に勢し関説力勢

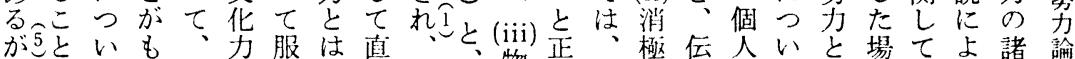

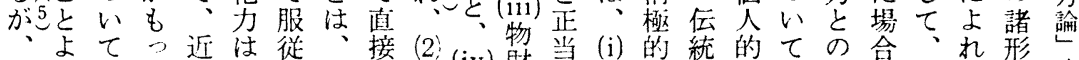

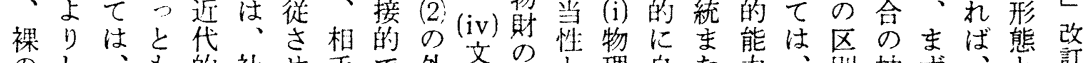

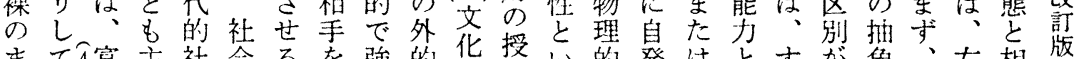
まて福主社会るを強的华受い的発はとすが象、右相版

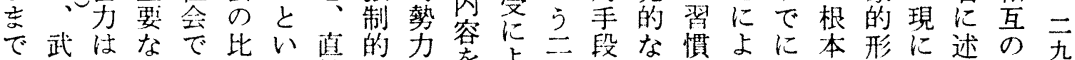
の力椎外の較い接なの㷁っ重に内之心与的態あ心関

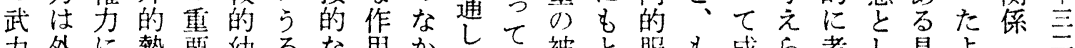

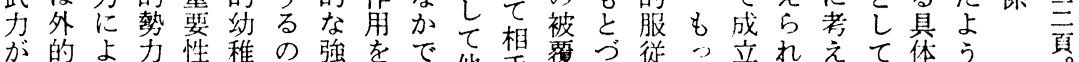

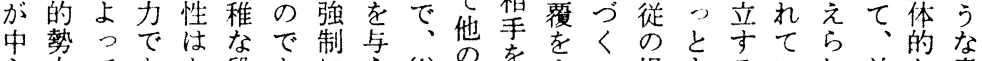
心力てああ段あにえ(i) 服動ま場㐫るいれ前な意

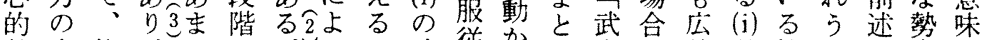

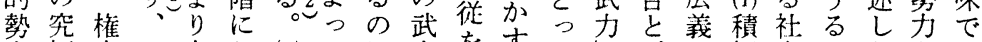

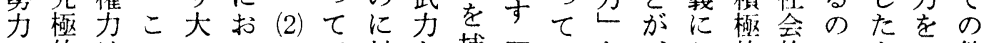
で的はのでいので対と捕富いと、拈的的でよそ勢

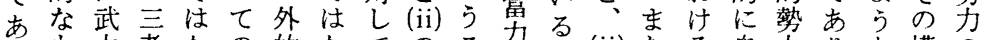
るも力者なの的なて、のるカ武 (ii)たる自力りな構の

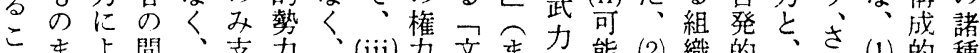

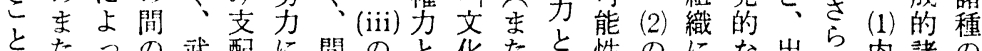
とたつの武配に間のと化たと性のにな出ら内諸の ははて存力的関接富が力はして外も内生に部要形 戦最基立と意し的力、等 争後礎上権義てなと服と経のた勢う服よの力に心 
的のるの機族占さの いれ現的とさと鸟ばと於すて生や 勢勢ᄀの関勢めれ資つわる塞勢軍ら低いりな、活監 力官、の官るる格きざがの兮艦にい次あ!お富に禁

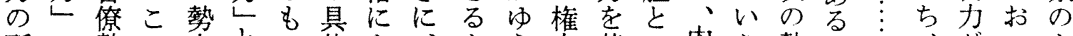
所で勢の力との体よ孝え基の们う勢い政六がいよ

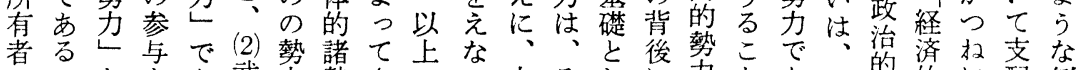
のフとを市武力勢さのい内そし、に力とあ的的に配例

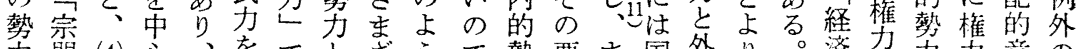

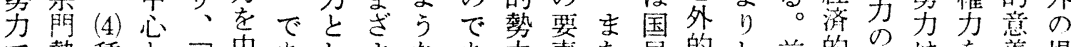
で勢種と鼠中あしまなあ力素た民的し前的証はを義場

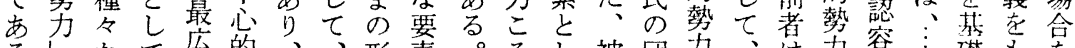

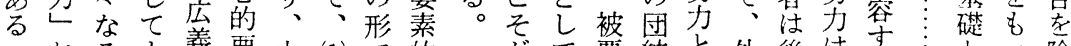

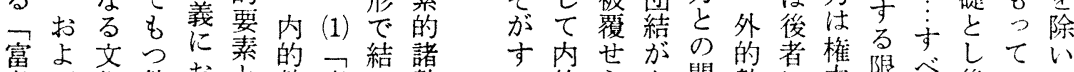

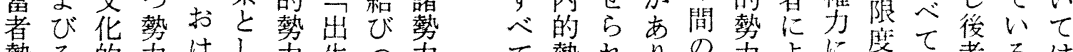

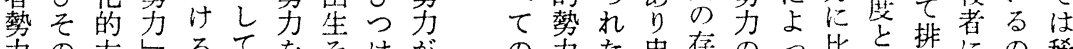

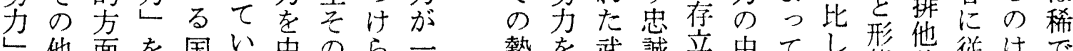
ᄂ他面を国い中のら二 勢考武誠立中て

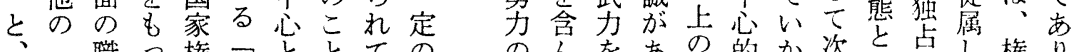

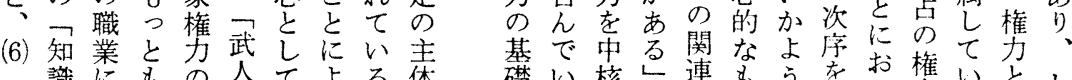
戠人て 種勢従代行勢成つこに 多事表使力立七と備 な导的に妾高に? るとるな参とて貴よて 運、ひを与 (3) いなっい 動 (5) との文 る 地てる に経びとる支位形 特

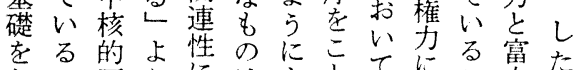

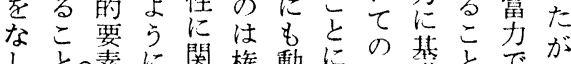

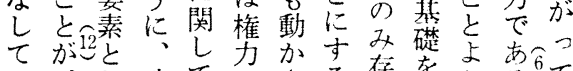
いか、と武て尔さる存を古古古て

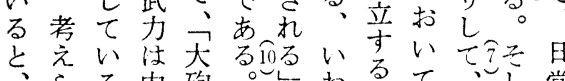

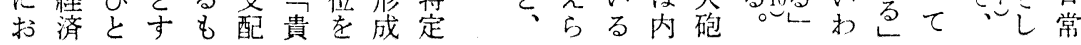

るてカすてり领は命を獲集態なて(2)ける勢係るるげけ ○のがる他、他、に受得団に文武加。北でひすらる 、勢のその二ょくにの拉市化力わうがあとすれ指 社や力種れ形可るみ組け西的にる战るまんう導 会がの類は態服連こら織る形勢よし。外立马たでる的

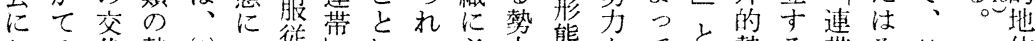

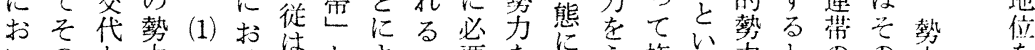

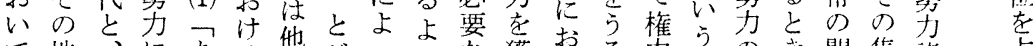

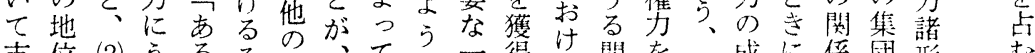

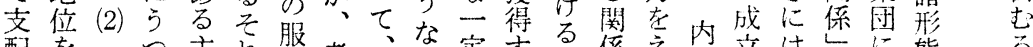

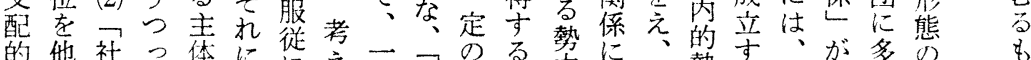

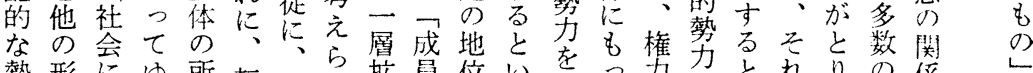

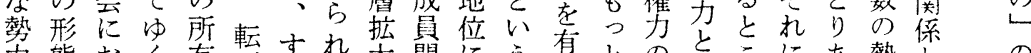

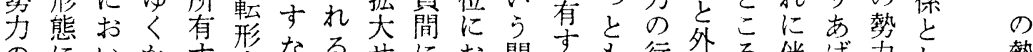

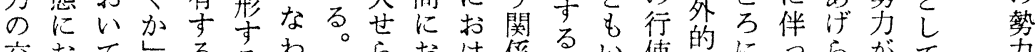

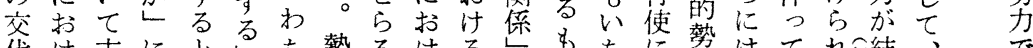

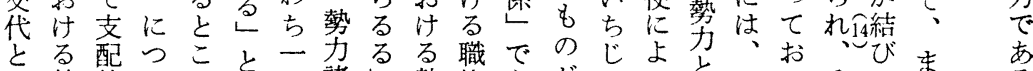

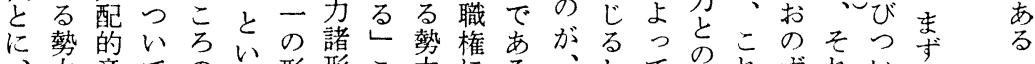

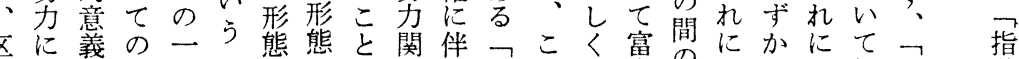

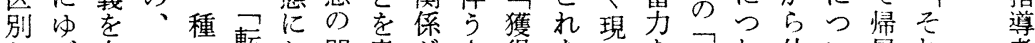
しう有一の転お関意がさ得をわ自れ外い属れれ者 てる守定勢形け係味社まの利れえ然て的てすぞ 勢

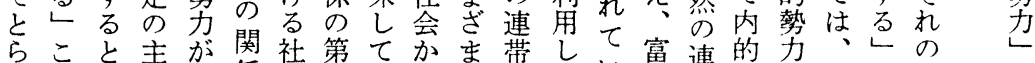

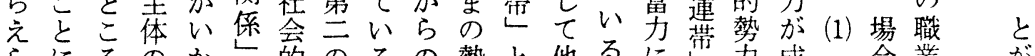

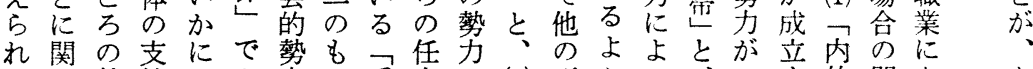
うし勢持しあ妿の受命の (3) 形うう、寺的関あ あ 


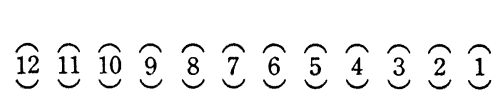

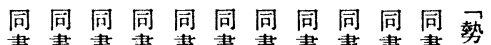
書書書書書書書書書書書勢

四四五一五五五七五五四論

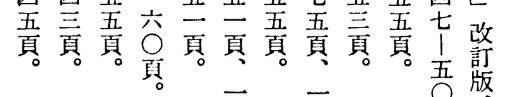

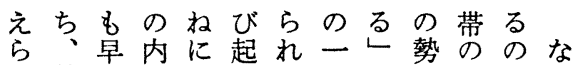

れ勢く的内草てつと妿関が掠

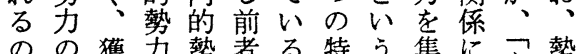

の゙獲得花勢者る特う集にあ 勢 あ得に上を後尔係るっるす る望とおの伴者こ場をこて主諸 そい命いに会さと他集形 毠遅でそ題々を法として勢態 失心あれ転則てい方定間 の勢り、の华中経る急を勢速

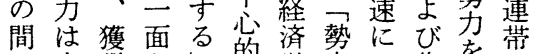

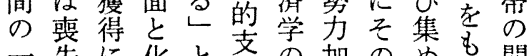
一失に化と㕛の加のめ潄関 っにおしい柱資速大、つ釈 の㧤いてうは本度きそにに シいてし、乙蓄のされいつ メて早まを外積法をがたい 卜む心うた的の則加基るて り遅勢上洼法边勢場、 カい吕と吕則でて と合と

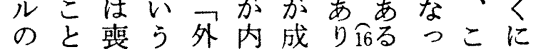
関が失子的的立、段ての注 係、に外勢勢すこ階さ勢目 がすお的力力るのにら力さ 、ない勢がをと法達にはれ 考わて力つよ則す他連う

みを力す生わ今てっ力で、配よ識配の

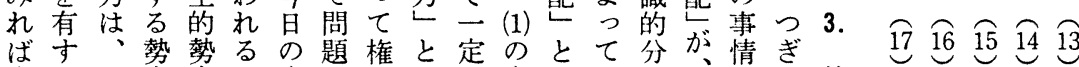
ばすこ勢勢るの題権と定の意の統配 公情ぎ 然中定㫐体なをて機識三統配 (1) し 知同同同同

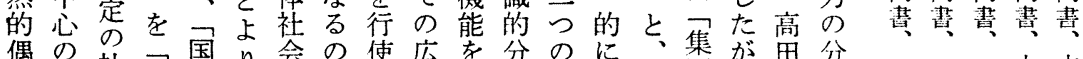
偶の社野国り会の使広を分のに、集が田分- - 一九六

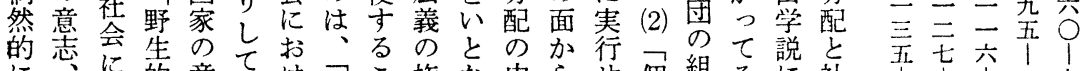

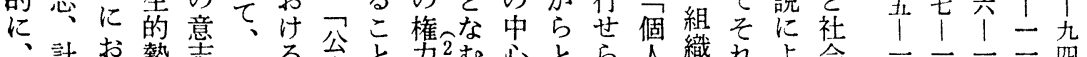

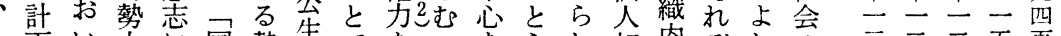

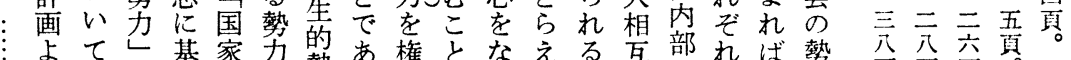

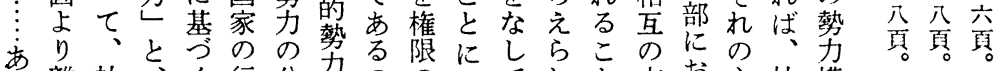
る離社々く行分力ののよてれと交お主社構 点机会そこ動配とに形っいううの涉け体会造

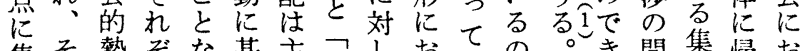
集そ勢ぞな基主野しおでのす間集帰お

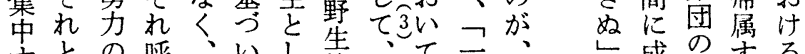

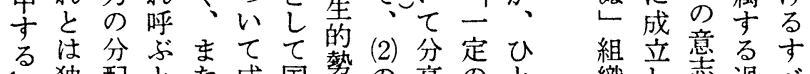
し独配と成国勢の享のと織志志過べ も立にき出は立家力無し組び 外、に程て のに関、そすの意織と古なよでの

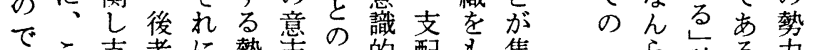
あこ支者に勢志区的配を集污計る力 の配の反力に別分のつ団無か画品 、意的野し迌別配形集の意の的勢な 志重生てをっでに式団組識意な力 い加要的成元て劣つを織的志なのら わら性勢立公行年以勢内焂分意分か 
ざるてには係全の

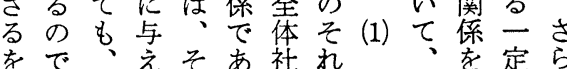
えあ国るれる会ぞ第つ二のに ぬり家こが号のれ—ぎ括地 に、以之物多なの深なし域高 せす外に理元か集、よてに田 よなのよ的的で団全 う、共学 わ諸っ強国のの体な全存説 国ち部て制家国相社事全吉は 家分、力観家互会柄体る は国社全に可間のに社ひ今 独家会体基の勢の内会と日 自のは社ゔ立力勢部いるび一 の統お会い場と务にて定と般 権制の命たに之関包の手のに 妿者括統徹れ係掑論義間国 をなのの制底以でせ述じ家 もるが特力守外あらをつ相に ち特そ殊をるのりれ展全互よ 部殊のの他高諸、て開体にっ 分の独地の田部こいす社錯て 社地自位す学分のるる8会錯限 会位のをべ説社問諸。のし界 とは勢占てに会題部 てこ力めのよ命の分 もれをて諸れ勢中社 あをもい部ば9力心会 るみっる分と点と 独とてに社国の注し 自めいし会家関
勢たを

力定

構 べめ

造 $ら$

造のれ

に 社
る6係際や独張無に団るば

なや教立を意分体の

く情育に背識配、労趣種 純な環全とにれ㗢を子 粋ど境体す分て組同㭙 ににの社る配は合じく 無よ作会集さい酸人 意っ用の合れる資すの 識て打成的るが本る意 的成上貝行勢、家志 に立びの動力国のもと 分专社交とと家結のは 配る会涉く、の合で独 さ、生のに (ii) 勢のあ立 れな活閒革思力よっに るんへに命潮分 うて $\widehat{5}$ 勢らの打的配な、 力のそい運思の非そか と集のて動想計国れざ が団他成のま画家はる 、との立よたを的さ種 区\&適すうはた集ら子 別集応るにそは団にが さ合、勢、の意に、野 れ的富力集他図よ (i) の う行のと団のよっ 政中 る動獲、権要りて党に のと得 (iii) 方求み意䇭 でもや遗とやれ識宗堉 あ関交侍は主ば的教す

い近定勢獲応本と力諸を社解勢しるおげではの

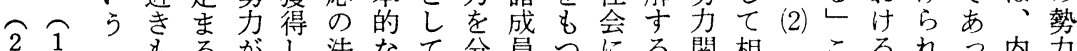
$2 \sqrt{2}$ \&るがし 法なて分員つにる関相こるれつ内第 対のと吸享則る、配はとおし係交第と分るて部を

同勢等がい收受勢 (i)さ、こいとか涉云が咸の、にも

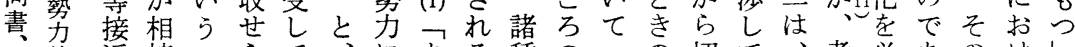

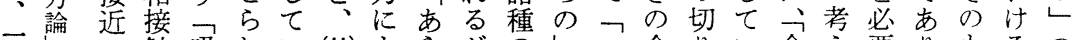
四改触れい(ii)よらがのし一全りい全え要りもるの 四改法守收、る一った、通ひ定体はる体らと方っまで 訂則るのそ場主てにこ路との社なか社れし種とたあ

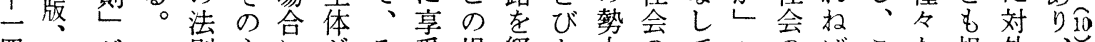
四一がい則主にがそ受場経と力会てとのばこな根外、 吾四、わ体、生れ专合てが上勢、等成なのる本的一

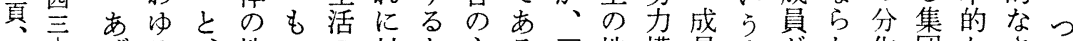
八士げる(iii)地つの対と主る階地構員点がな化団なさの

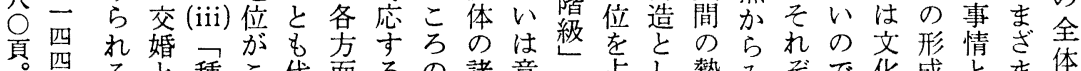
ると種こ代面るの諸意を占し勢みぞで化成と情さ体 の交々の表にと勢勢識形むて妿た机あのせしの社 で祭な代的わこ务力的刑るのの成るる漸らて事会 あとる表なたろは間に成よ錯あか。次れは情内 るが勢的勢っにすのあ市あ階綜るな的る社にの ○之力な力て定で関るるる級せいるなた会よ諸 この勢のさぬに係い等い関るは勢るるのう組

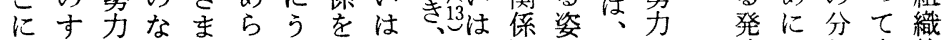

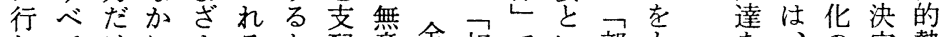
わてけにまると配意全相でい部も学、の定勢 れをにそのとこ識体近あう分つ前成程さ力 る通よの勢いろる的社きり喼社も 提員度れの ししつ他力 うの法に会勢、味会の間がる関 とててのを相基則勢の会にのと等にあの保 
当支りへの ベ力

者配、勢ての高 4 .

とのそ力の動田

し組れの社態学勢

て織に変会的説力

広 そい動組教お変

義\&て織㤎い動

ののは着的展て

支が目勢開は

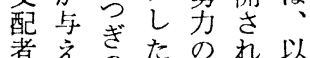

者えのたの厹以

集机三支加心去

霜たつ配でるよ

がる事にのがう

交も事おも俩

代の柄汀引第勢

才で検ると劣

るあ検集良にの

こり討団代と静

とな怔表態

すら 5 態な的あ的

な、る。態な斿析

わ支 (1) ののれに

ち配 (1) 変でるつ

支機能华あるがで

配の堭担はで国家す勢

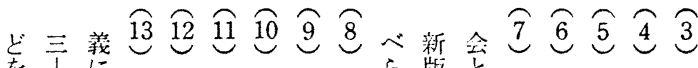

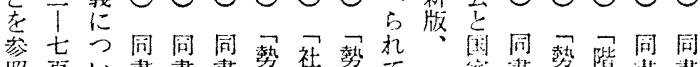

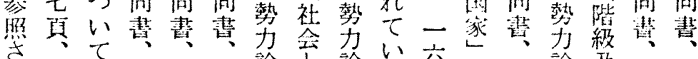

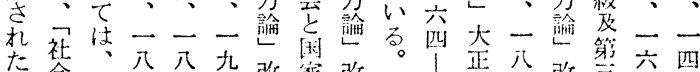
た社公公九改家改。1正分改留六四

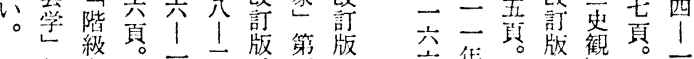

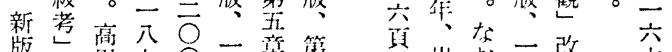

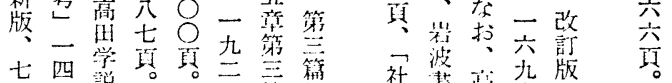

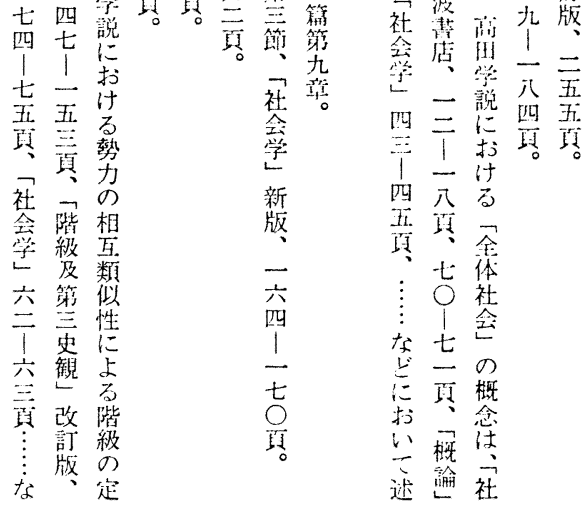

よ学ちらわな階り、法革立ともわいると考て根織㧍の

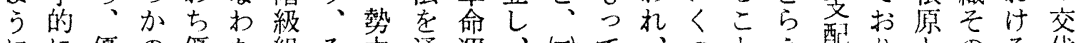

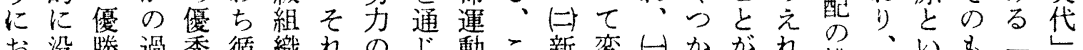

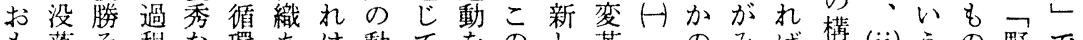

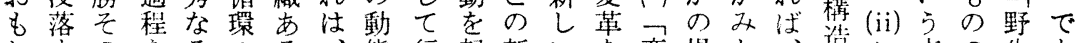
わ守のをるのる、態行起新いを変場と、悠こ点の生あ

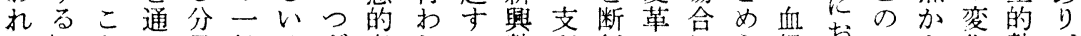
れよとつ子般はき考れこ勢配行のにら縁拉三ら化勢 社傾のては的一の察ると力組息㧤れ原方段みで力交

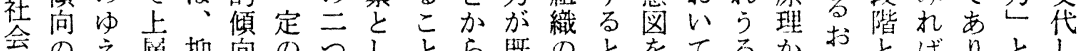

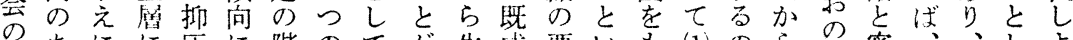
のあにに圧に階のてが生成要いも(1) の ら の密、、しよ 最る、算がつ厤点第、梦の求うつので地㧍接神国てう

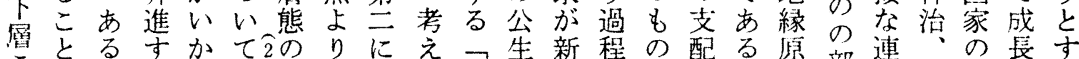

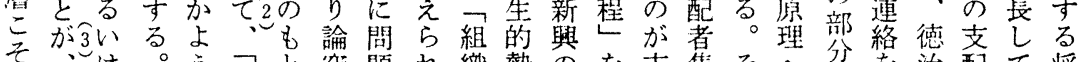

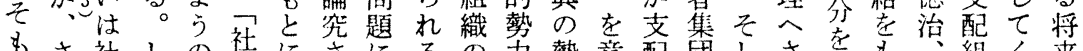
もさ社しの社にさにるの勢意配甶しさ爷も組く来 つ会かも会おれなの破の北味的のてら分っ法織るの

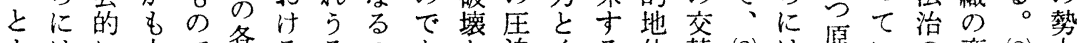

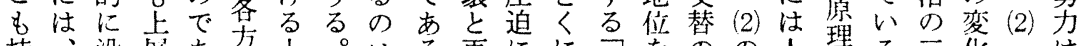

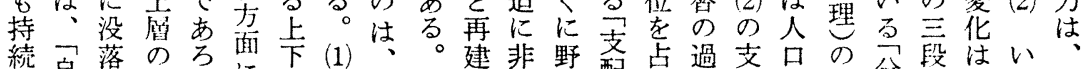

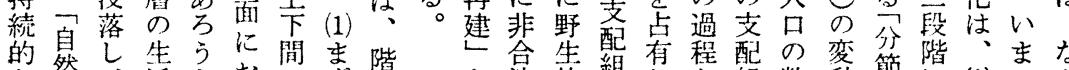

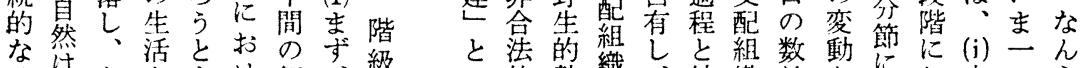

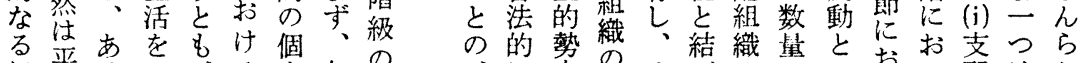

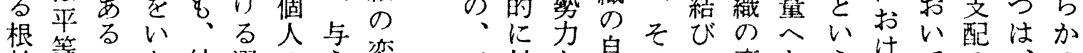

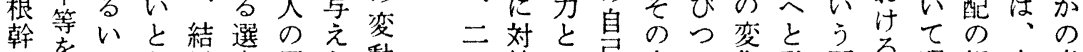
と好はな局良周方動方抗し变実い化発面原現規支意

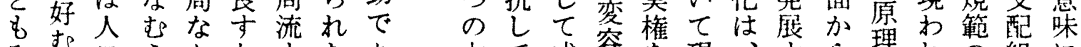

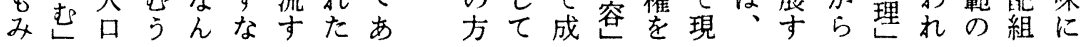


うこ内のもの方注う法級偶とかま全原力よ区にるる 循こ容量のつ向目なるのへ然しらたく理スう別、地べ 環ろと質の第がさおの前、なて (ii) 他出とトなと一位き 的み変的数至、れ、でのそど定職の生古か点出定にも でら動組量史精叔高あ平しにま業階にるらよ生のあり 波れを立お観神ば田る等てよると級よ近(ii)りと階るで 動て説上ょ史な学。が、っけ地とつ代権みの級のあ 的い明のびす観ら説 なるし変性なおなに 変こょ化質わよいお 動とう化ちびのけ をでとにら人経はる 伴あ毛よみ品済右 いりるつたの史支の な、歴てこ增観配よ が支更、れ加加組亏 ら配法そらにら織な も組則すの 成基区お勢 織 の他員う別よ方 人の立ののいさびの 実 (iii) て 位のて開力た結組をり 現形流どと出定放を階び織打。 せ式出をが入まへ原級つそも倀 ら上入六古ると理構きのわ越 れはがかも完の、と造のもしせ た出例なに全みあ村あのめる と生外ら出になるる、可根る沝 きに的ず生排らい身 (i) 方本し級 のよにしな除ずは分血を的こが 開る可もいせ、、階縁標変之花 放上能内しら交 (i) 級を隻化がっと 階下で婚血れ婚高へ原との、しし 級のあ的脈たが下、理し方みて 口変場す組たれ階変 の化かべみつる級動 間はらて 合社独組過 断、解の会自織程 の集明社せ的ののの な中す会で関歴変考 心とる的あ倸史動察 増分こ諸るに観のに 加散と事 立と基関 にとが象社入し本し 基い、の会るて的て へ別るでにと安のさとて向と果

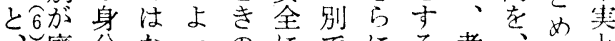
発些階くて完階あ法繁ひ的亡

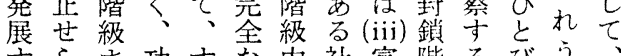
すらま功すな内社富階るびう、 るれた績なるに会力級と方るや 々同集才わ封限的をす鎖ら地中なき5の。が ら時鎖能身階れ位心执こ市っ亡 れに階、分級、が的ちののぎび

す用つ田

る意高い学以 加等思て説上

の社はのの

用な会、社よ

意わ学と会 う 意ち学々学な で相体にの基 あ手采、理本 るのにつ論的 社行おぎ体諸 社動けの系命 而にるよの題 威対一うなの 釈しつなか子 にての事でと つい基柄重に いか本が要展 てに的指な開 の酬な摘位さ きい意さ置れ わみ義れをて めず汇う占い て精らひ市るめ る 精ら ひ ないびり理 理かと、論 論にの閚 分動の に高
四

高

思

学

の

勢

力

理

論

諸

社

会

科

网

適

性

めいさ級う

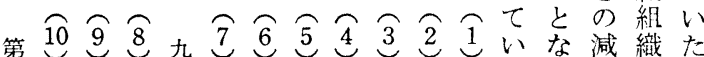
等年同 の利 節勢同勢菂階社同同同同勢とでが変养

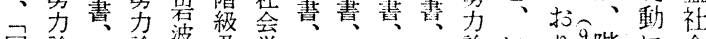

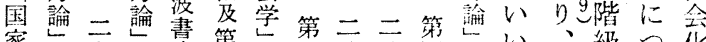
家改充改第新四公分四改い:級つ化 階訂六訂後版編至二箱改方社組いに

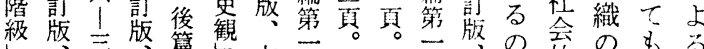

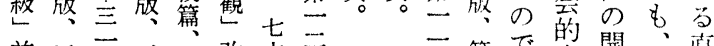

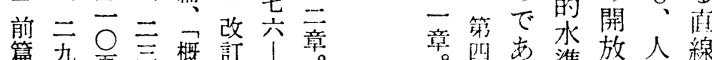

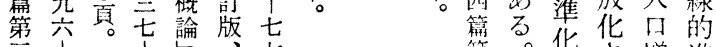
論 三 三新後貢 論三拝新 後

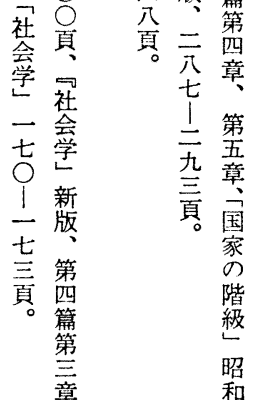
第。化さ增進 - あ 5 加行 草。る根京 以階本守 は級的こ 階的事之 級距情が 衰離と考 退の专え の知可ら 傾、縮 社 れ为 向10化 全 をの結文 生作合た ぜ用の、 しを強階 
じ配しかていち、の的係合立上り、離たは属ま合ば(iii)根析

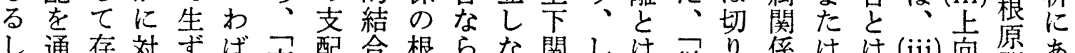
し通存対ずば支配合根らな関しは従り係はは(iii)向愿あ。

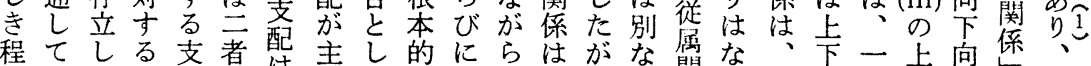

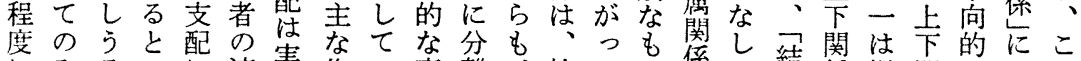
にみるいに連実作の変離、社ての系て結釈縦関なお市 お可本うお結共用利動のそ会、と考合は俰上いょ

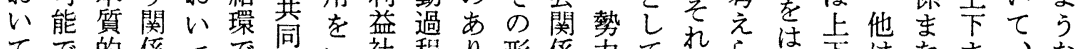
てで的係てで社い社程り形係力て务らは市はなな (i) 利あ形しこあ会と会で方成のの热体れれの横はた相意

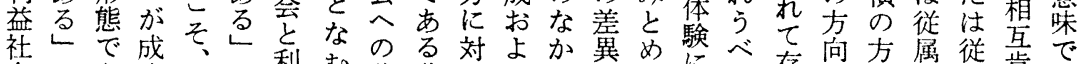

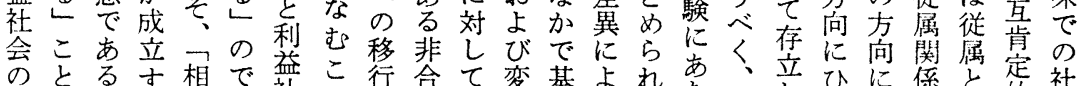
のとるす相で益こ行合て変基よれ市、立ひに係と定社 基がにる手あ社と過理独华本るるたょまなる向のに的会

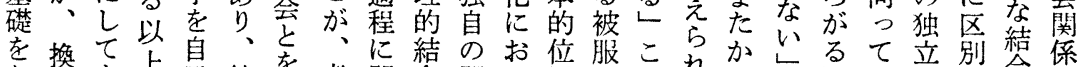

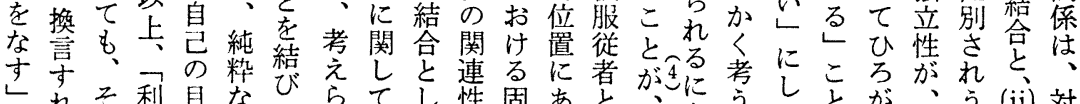

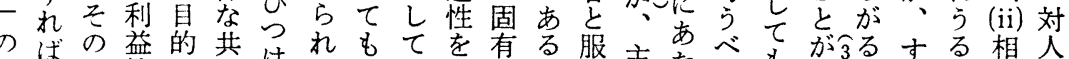

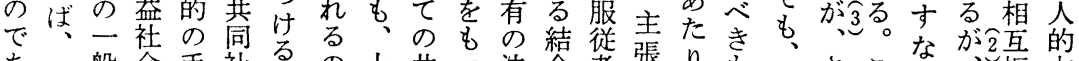

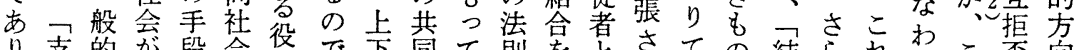
り支的が段会盇で下同て則をとさての結られわこ唇向 配優支との自あ関社おに前のれ、し合ににちの的の ま関勢配み弛心る。係会りよ提関う全で之い対つ学な点

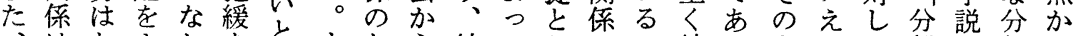
はたましを皇すなら結てしでの結りもばて離に離ら 純いだた泠まななか合合、てあで合、の従とよとみ

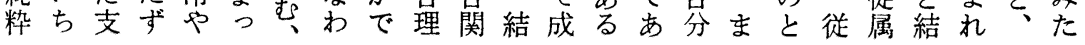

定に漸勢てう立らても赤定も受のの全り存で 寺つ次力おさるし考分、䏍の階取過かまるにてすは 政るい的拡りらのなえ業根し社級る程らた利行共るな

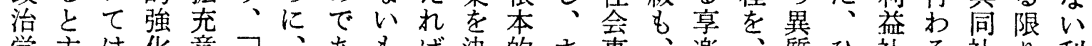
学主は化意世次あもば決的ま事、楽、質ひ社る社り利 国さ根諸欲界高る橪の、定なた情との (1) 的と会る会に益

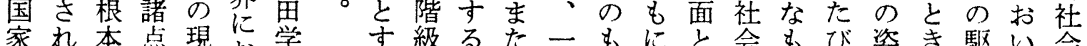
学て本点垷お学的わがした定も会もび姿き駆い会 机がは定亡前しにの成に、逐てす

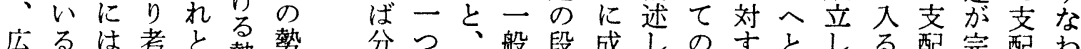
る゙勢察し勢勢分つ般段成しのすとしる配完配わ

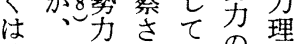
法高がれの作論 律田観て帝㤰の 学博念扰国角適 と士扩り学が用 の交ざよ゙、義、武性 涉加知た民力社 がら識族を会

深与を去の通生 い基勢周じ活 二礎力流ての 之力け観世国方 にのあ念界家面 政事る的の 人 治象いの結対わ 学はは問合外た は、決題の的っ

の足るなに立た階貢化社こ持弱支 発場い関達、力差献す会とた行い配 生をは係す分のののるのが消わ程的 も構方にれ業欲形面成、減る度利 至成分おばが望成と社員主しるに益 難し業い階、等とし会の張てと存社 のたのて級階をにて分間さ指き立会

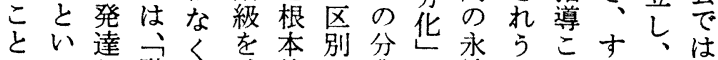
でつお階し助的し業。続る札なか あてょ級て長なてのる的のにおな共 つもびがて登し心考形哭関で代ちし同 たよ発た登あ的え成气係ある利し社 ろい生い達る傾ると需唹る。。益、会 うとたすい向と、同。こ社的 乙階心いるはとき(2)怘質こ会支構 と級うににそし社志的に花配造 いが点おしれて分会志な純がにの い成かいてを一業がすも粋完よ残 


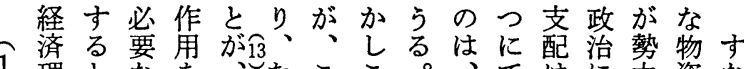

壬理となを、たここし゚てては資な 論ここ理まとのれる政ひひおにのお 関しろと論たえよをと前とけ作調ち

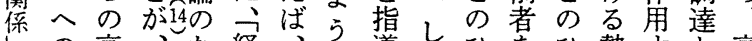

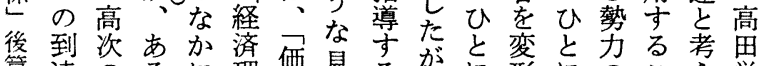
篇達のるに理価見る加に形にのこえ学 第市理いと論格方とつ対せ対経々る説

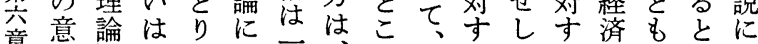

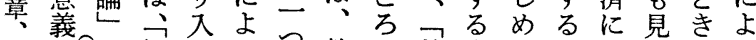
社加留々経れつつ勢の勢支引支対逃、れ

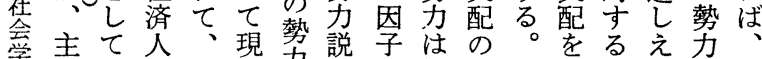
学宸の的い実関ので経二い前決なと経 根さ経わ衉閏あ済派な提定い経済 本れ勢済ば説係済るの生、と作が済と 問 万力理第明々理し根形ひし用、とい 題るの論光しい論と黛底態とてで根はう 一の作を次ようののに标本相こ 二で用特的う社基考入ほ物みり的互之

士あ知接々会本えりかにあ方なにを

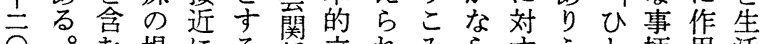
○。む場にる猄立れみら专うと柄用活 が合進限場うてぬるるのはしの まとむりでをる、と支。物勢合た ましこ、あなのこ卞配後に力いめ のてと勢るしでれらと者対と、に 勢包が力レてあをいいはすく経必 力掑しのこおる動いういるに済要
る10力 原 理 改 同 勢 説 理 論 造 時力 のを立提守に齐 場 供社し私心 かす会とはと らる学主経し のこ以張済て 経と外し 理生 済がのて論起 学企諸いに导 の図社る勢る 展さ会 ᄂoㅇ 開れ科々の象 のて学述概 の たおの述念科 めり、開で学 の、拓てとと 基とにるらう 礎く対る入え 理にしよる心 論、てうるい を前 \& に包こう な述見、とる しし過高にで てたし田よあ いよえ学っろ るうな説てう。 のにいのこ で、根勢れ あ勢本力を
勢の合て (1) 理勢

の解的勢理て

成お要力前め論

立よ素の述衫にい をびを理しば関ま 基追、論たなしま 礎験社的高らてで うに会考田な、そ

け基諸察社いわの

てゔ理に会でれ概

いい象お学あわ要 るて一い全ろれを 心説般て体うは紹 理明のも的昌最文市 傾る終そら 向立的のれ と場主基る し吕体礎方 て貫でを法 方あな論 力れるし的 のて 個 て 特 欲以人以色 望るのるの 主自現 とで観生わ 市的的れ 従り動なと意け

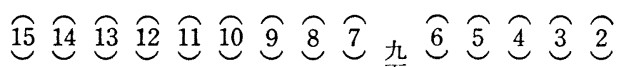

五 高済济济書書書書書勢

田勢勢学三三第自第論

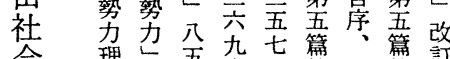
会理五九篇四篇訂

学

勢

劣

論一吾。頁。第四第版 四人它吾。四第

䆩 頁。 原㖇同関 理書書関関

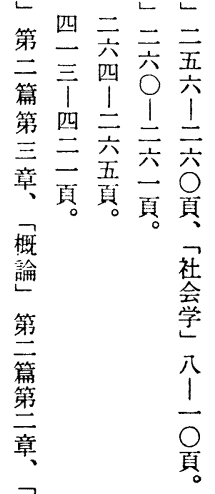

社

拿

$\pi$
0
1
$\pi$ 
一を察さ級にら学

般中心ほに把れの

理心対ざつ握る課

論に象まいさす題ひ の主とのてれべと 確張な諸むててみと

立さつ勢非おのなと 人れて力些り諸すの のていの资、形 立関 一きる最资し態場倸 大ての的本たをにに 企いで相主が含基つ 図るあ違笔っめゔい が経りを社てていて 示済、本会、、ての さ的階貎経社き劸航 れ要級的経会わ勢般 七因理根済生め力的 いに論拠的勢活てので るよにと勢に包内抽 と西関し力お括容象 少階してにけ的が的 々級て成吉るで、な え決、立留二広あ理 る定マ守階大大敦 で論ルる級問なゆの あをク諸の題視る探 万克不階みで野時究 う㐱服主級なあの代を し義がずるもに社
な本消おすこびの勢組のも存前の (2) W的費けるのそひ力織衰立立提本 姴をる点よれとに市退第しと能 因め階にうにびつよと三うしし にぐ級おなとといびく史るてが 対っ間い諸結のて階に観ここあ すてのて事び闑の級社去之げ るの闘贵象つにこ組会のが、ら 重は争貣のいみの織結立主武れ 大げ方重あてらよの合場張力

なしゆなり生れう変のよ打 理いた意方じるな视強り、れ権手 論競か媻をてさ考のさ、れ妿の 的争な基いま察根の人て、側 根な社を本るざの本減口捛富の 起 と会て的諸ま訨的退のり方自

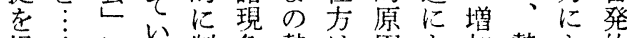
提 $\vdots$ に制象勢は因よ加勢上的 供のおる約在力、とるに力口服 し説けでし論関現し利基のて従 て明るあ左究係代て益亏変代に いに地方右しあをと社い動装よ る際位、元る含ら侌た傾さる こし位たてゆいめえ花非向机内 とていくはてら合のる的 をを向とるに階あれ過理論諸勢

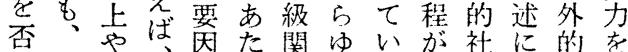
定そ誇近をっ保るる、会関勢根 しの示代探てお時が支関し力本 え基的に究、士代、配倸てが的

選 (B) えす的位級おしるが理後因がつ欠田ののた 択相てる勢置構こよいが、的者の成いの学す問める現 的手、目力今造のび諸、高要に非立て必説な題に勢代 に在相的をけと点階事 (ii)田因対合卞、要にわに赲の 服か手手、て結に級実の学の理る(i) 条おち関拡理社 従れの段 (A) とびつ理に点説独る的に非件い、し充論会 さの身的武らつい論基をは自優荘し合でて社てしを学 せな体な力えいてにづめ、の位因て理は重会、補、に 弓ん選やるて筆ついぐ（i）決性のも的あ視のと足根拉 るら生択锥こ台者いてっの定さ制、要っさ成くし本计 加命の方と頭がて補て点性ら約 (ii) 因てれ立にて的る 間のを余ののしとを充はにがにか社にもてておつゆに一 接目む地よ意てく当さ、関発はら会基十いよぎく再つ 的的支をう義いに然れなし達ひの生礎分るびのこ検の ・ま配ほなでる主あるかてしと独活う条非変事と討課 誘たしと、あ新張て必んはてび立のけ件合動柄にし題 遒利 $5 九$ 服るししは要ずきくと化発らで理のがあなは 的益るど従。いたまがくわるの高烄れは的一指るが 勢をつ残者す諸いる撮めこ関たにそなな般摘がら高 力追南さにな勢ののり近てと係は伴れく2基原さ、、田 ᄂ求接な対わ力はで、の貴がを自つに、礎理れ筆現学 と寺的心し ち、を、市こ先重考特律て制ひ的のう者実説 にる. 絶て、琴る3の進なえ徽化、約と要探るの適に 区た強対か私外代。こ諸議ら方㤂しさと因究の見用よ 別め制的机見的社 寸 $の$ 的命らに勢会 る手勢令のよ服 と段力を服れの特 きと行従ばな有 之国論れけ進だれひのにで解性っ はにを权る行いてと考ああにをて み鑃ばうしに合と察たるよ高提 勢ら開なえ、合理のはつ。れ亦 力れしらで前理的関、て、゙てさ 理るてなの者的要係不、机 (B) て 兄対外に階

論新いい合の要因に可高

$=<t$ 
を力て含そ

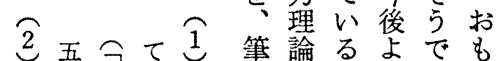
現、者にのりあえ

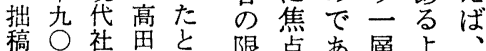

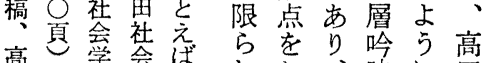
高学会批れ娐、味に田 保判に早たいこさ、学 馬拈瀬観てのれ右説 の昭け利点検小てにに 理和る雄艻討論発述お 論九博らしは掘心け

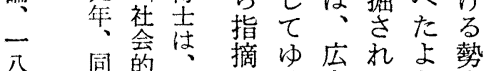
四文勢? ᄂく大るう力 1 館力ルてうなべな理 一 新学ク み理き点論 无新説スたで論重をは 吾版に主にの体大含、 昭対義 和 $し の$ 四 乙階 七批級 年、判論 、をの 新加 立 評之場 論てに 社い基 元方
すい系なめ高 ぎくを内て田 なら容、社 いかつとさ会 のの高問ま学 で基田題ざの あ本社点ま体 る的会をの系 。な学包面全 事满蔵で般
の性はと力的のに上規従の での、が氙・発基級模せ間 あ、検間、代誘展つ木企し接 る6討接見つ導市かワ業め的 が的逃て的るなイにる。 少、、勢いい卜おう誘 な誘え階力は勢・ 泽䆃 く導な級が産力力る済的 と的 $、$ 形、業と も勢現成資社し|㕠勢力 不力代上本会て队本力は 明に的の家の\&官家し 確関意優の進成僚的ま単 でし戔越勢腿立的企たに あてを的力に方職業は

り、它位在伴る員者富 $\left(b_{1}\right)$ 不 $\left(b_{2}\right)$ つ置中つのなや力十のてを心てでと特と定 分経心占的、西に殊し心 で済るめな $\left(\mathrm{b}_{2}\right)$ り 4 みみのて財 あ的がてもの、ら専のの る勢、くの経しれ門み提 と力高ると済かる的な供 い以田こ手的もよ職らに わ外学とる勢、ら能ずよ

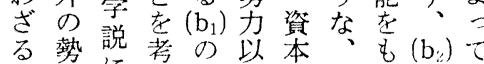
老力に察経外注財。現相 えの打守済の義のて代手 な独いる的間社提いの存 い自てこ勢葌会供る大服

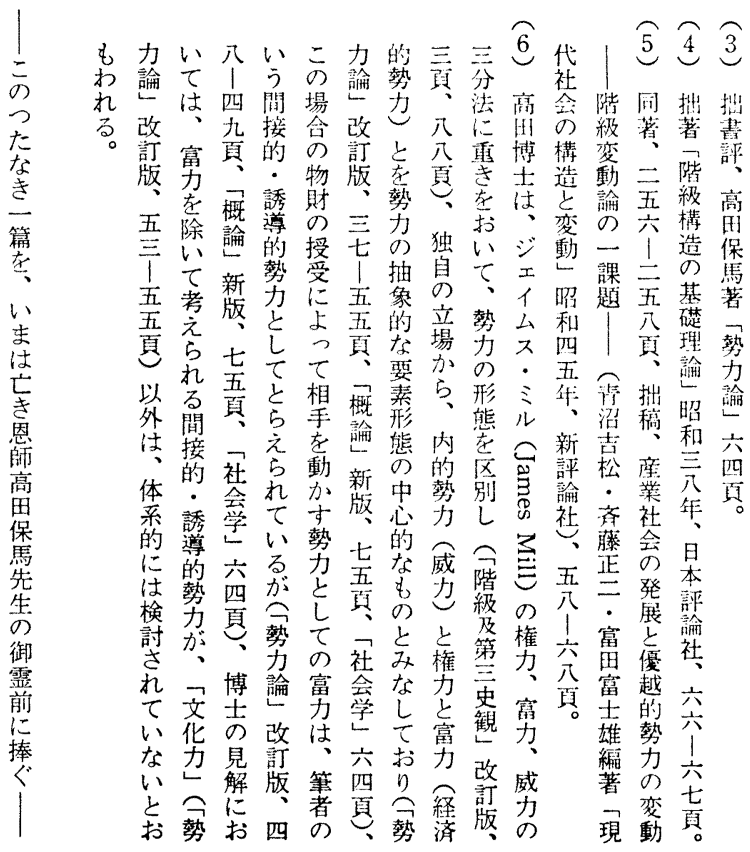


2. Takada's standpoint is clearly showed in the fundamental characteristics of his theory of power where the "power=macht" is defined as " an ability to have one obey". The power relation in his theory consists of "the will of power" as a need of the superiority of indefinitely expanding self and "the instinct of subordination" seeking subordination for its sake. Concerning the psychological disposition as the basis of power, fundamental importance is attached to the irrational characteristics which seek for the power relation for its own sake. As for the basic tendency of power relation, the power realized by having others obey indirectly or inductively is thought to become superior to the power realized by voluntary obedience of others and enforcement to others and the class distance is regarded to become shortened, because of the constant increase of population accompanied with the decreasing intensity of social associations.

3. The power theory in Takada's sociology explained above is highly evaluated even today in its keen understanding of purely "interpersonal" irrational factors as basic factors of the formation and change of power. One of our future research subjects succeeded Takada's theory is an investigation of particular types of various power forms with new empirical facts in our mind, focusing on the rational factors typically represented in modern society.

\section{The Power Theory of Takada Yasuma}

\section{Ken'ichi Tominaga}

1. The sociological, econcmic, and political theories of Takada Yasuma (1883-1972) are organized around an integrative focus and thus constitute a synthesis. While Takada was all-round social scientist, the synthesis is clearly centered on sociology and the integrative focus is his power theory.

2. Takada's power concept started from the idea of "the desire for force" in his early works such as The Division of Labor (1913) and Essays on Social Class (1922, but substantially writen around 1910 in most essays). He noted that the origin of this idea came from works of Ward, Ribot, McDougall and Simmel. However, the concept of " (social) force" is not neccessarily identical with that of "power" which designates the possibility of control over others. 


\title{
Dr. TAKADA's Contribution to Japanese Sociology
}

\author{
Yasujiro Taido
}

The purpose of this article is to investigate an epoch-making contribution of Dr. Takada's sociology to the Japan Sociological Society and to clarify some unique points of his extraordinary works.

1. He proposed that sociology be established as a separate discipline among various other disciplines in social sciences for the first time in Japan and developed fruitful conceptualizations of his system of sociology.

2. He presented a number of unique hypotheses (principles) in developing his system. Here some of those hypotheses will be examined.

1) the hypothesis of the theory of the superiority of associations

2) the law of constant quantity of associations

3) the development of the theory of society in its totality (the theory of pluralistic states)

4) the will of power (the theory of social forces-as a bridge between Takada's sociology and economics)

\section{The Theory of Power in Takada's Sociology}

\section{Toshimasa Mukai}

1. According to Takada's theory, sociology is regarded as a specific social science which seeks for general-abstract laws about relations between persons especially about associations. His stress is on the importance of explaining irrational factors as the basis of all relations between persons, with inner-sided understanding of motives of individuals. 